\title{
New insights on the only bothremydid turtle (Pleurodira) identified in the British record: Palemys bowerbankii new combination
}

\author{
Adán Pérez-García
}

\begin{abstract}
The British record of Pleurodira is very limited compared to that of Continental Europe. It is restricted to two lower Eocene coastal forms, corresponding to two lineages of Pelomedusoides: Podocnemididae and Bothremydidae. One of them is a recently recognized indeterminate species of the podocnemidid Eocenochelus, represented by a single individual from Bracklesham Bay (Sussex). Eocenochelus is a lineage of African origin that reached Europe during the Paleogene and is recognized in several European countries. The other British form is represented by several specimens from the London Clay of the Isle of Sheppey (Kent). Several shells were identified there, since the 19th century, allowing the description of four putative new species. The detailed study of the classic and subsequently found specimens, including unpublished individuals, confirms their attribution to a single species, for which the new combination Palemys bowerbankii is proposed. It is the only pleurodiran turtle recognized in the British record at a specific level. A neotype is designated, and a new diagnosis is provided. Photographs of most of the classic specimens of Palemys bowerbankii are included here for the first time. The detailed study of all these specimens improves the knowledge of this species. With this information, this exclusively British form is included for the first time in a cladistic analysis. It is not interpreted as the result of a Cenozoic dispersal event from Africa, as was the case with Eocenochelus, but as a member of a well-established lineage present in Europe during the Late Cretaceous, which lived in this continent at least until the early Eocene.
\end{abstract}

Adán Pérez-García. Grupo de Biología Evolutiva, Facultad de Ciencias, UNED, Paseo Senda del Rey, 9, 28040 Madrid, Spain. paleontologo@gmail.com

Keywords: Pelomedusoides; Bothremydidae; early Eocene; London Clay

Submission: 11 January 2018 Acceptance: 2 July 2018

Pérez-García, Adán. 2018. New insights on the only bothremydid turtle (Pleurodira) identified in the British record: Palemys bowerbankii new combination. Palaeontologia Electronica 21.2.28A 1-12. https://doi.org/10.26879/849

palaeo-electronica.org/content/2018/2268-british-bothremydid-turtle

Copyright: August 2018 Paleontology Society

This is an open access article distributed under the terms of Attribution-NonCommercial-ShareAlike 4.0 International (CC BY-NC-SA

4.0 ), which permits users to copy and redistribute the material in any medium or format, provided it is not used for commercial

purposes and the original author and source are credited, with indications if any changes are made.

creativecommons.org/licenses/by-nc-sa/4.0/ 


\section{INTRODUCTION}

The British turtle record includes several Mesozoic members of the stem group of Testudines, as well as a great diversity of representatives of Cryptodira, both from Mesozoic and Cenozoic horizons (Lapparent de Broin, 2001; Joyce et al., 2011; Pérez-García, 2012; Bardet et al., 2014). However, the British record of Pleurodira is very limited, being restricted to only a few relatively poorly known and poorly represented forms from the lower Eocene (Gaffney et al., 2006; Pérez-García and Chapman, 2017). Several events of dispersion of this group of Gondwanan origin to continents that were part of Laurasia are known, and more specifically to Europe, both during the Mesozoic and the Cenozoic (PérezGarcía, 2016a, 2017). Two successful lineages of Pleurodira are identified in the Eocene levels of Europe: Bothremydidae and Podocnemididae (Lapparent de Broin, 2001). The podocnemidids are the best represented, showing a relatively wide diversity. This group is represented in Continental Europe both by freshwater forms (i.e., several species of Neochelys Bergounioux, 1954) and by the recently described coastal genus Eocenochelus Pérez-García, Lapparent de Broin and Murelaga 2017 (Pérez-García et al., 2017). Eocenochelus is known in the Belgian, French, Spanish and Italian records, as well as a single specimen from the upper Ypresian (early Eocene) of Bracklesham Bay (Sussex, England) (Pérez-García et al., 2017; Pérez-García and Chapman, 2017; Pérez-García and Smith, 2017). This recently identified fossil, corresponding to an indeterminate species, represents the only podocnemidid specimen currently known in the British record (Pérez-García and Chapman, 2017).

Several shells and partial shells of coastal bothremydid turtles have been found in the lower Eocene British record, since the 19th century, from the London Clay of the Isle of Sheppey (see Owen, 1842, 1858; Owen and Bell, 1849). They were attributed to four different species, 'Platemys' bowerbankii Owen, 1842, 'Emys laevis' Bell in Owen and Bell, 1849, 'Emys delabechii' Bell in Owen and Bell, 1849, and 'Emys conybearii' Owen, 1858. Williams (1954) indicated that all of them could represent a single species. No detailed review of these specimens has been made after the study of Williams (1954). In fact, although drawings of some of the classic specimens were included in several works (presented by Owen and Bell, 1849, and reproduced in subsequent papers, see Owen, 1849; Williams, 1954), no photographs of any of these classic specimens had been previously published. With the exception of its holotype, which is identified as lost since the 19th century (Lydekker and Boulenger, 1887), photographs of all the classic specimens are included here for the first time. In addition, shells subsequently found, including several previously unpublished specimens that add to the knowledge about both the shell anatomy and variability of this species, are also analyzed here. Photographs and schematic drawings of the more recently discovered specimens are also provided. The detailed study of all these specimens supports their interpretation as belonging to a single species, represented by both juvenile and adult individuals. A reconstruction of the complete shell of this taxon is done. The new combination Palemys bowerbankii (Owen, 1842) is proposed, and a neotype is designated. Additionally, this coastal bothremydid turtle is incorporated, for the first time, in a phylogenetic analysis.

Institutional abbreviations. GSM, British Geological Survey (BGS), Keyworth, Nottinghamshire, UK; NHMUK, Natural History Museum, London, UK.

\section{MATERIALS AND METHODS}

The detailed study of all the specimens of Palemys bowerbankii identified in this manuscript, including those previously published (except its holotype, now lost) and other unpublished specimens, is performed here. In this way, the shell of this generally considered problematic taxon can be characterized in detail.

In order to evaluate the systematic position of Palemys bowerbankii, it was coded in the data matrix proposed by Pérez-García (2016a), which pursues the study of the phylogenetic relationships among the representatives of Bothremydidae (Appendix 1. The recently described European Eocene bothremydid Tartaruscola teodorii PérezGarcía (2016b) is also included, following the codification proposed by Pérez-García (2016b). Thus, the data matrix used here is composed of 180 characters and 31 taxa (Appendix 2).

This data matrix was analyzed using TNT 1.0 (Goloboff et al., 2008) in order to find the most parsimonious trees (MPTs). The outgroup of this analysis is Proganochelys quenstedti Baur, 1887. A heuristic tree search (Traditional search) was used, with 1000 replications of Wagner trees (using random addition sequences) followed by tree bisection recognition (TBR) as a swapping algorithm, saving 100 trees per replication. To test the robustness of the phylogenetic hypotheses, Bremer support and 
bootstrap frequencies (absolute frequencies based on 1000 replications) values were also obtained using TNT. Equal weighting was used for the analysis.

\section{SYSTEMATIC PALEONTOLOGY}

Order TESTUDINES Batsch, 1788

Suborder PLEURODIRA Cope, 1864

Hyperfamily PELOMEDUSOIDES Cope, 1868

Superfamily PODOCNEMIDOIDEA Cope, 1868

Family BOTHREMYDIDAE Baur, 1891

Infrafamily BOTHREMYDODDA Gaffney, Tong and Meylan, 2006

Tribe BOTHREMYDINI Gaffney, Tong and Meylan, 2006

Subtribe FOXEMYDINA Gaffney, Tong and Meylan, 2006

Genus PALEMYS Gray, 1870

Palemys bowerbankii (Owen, 1842) new combination

Figures 1-2

Holotype. A partial shell, now lost, first figured by Owen and Bell (1849, plate XXIII) (Figure 1.13-14). Neotype. The almost complete shell NHMUK 39449, which is the holotype of 'Emys conybearii' Owen, 1858 (Figure 1.1-8).

Other specimens attributed to this species. Five specimens, consisting of partial shells, including the holotypes of 'Emys delabechii' and 'Emys laevis' (Figure 1.9-12, 16-33). All of them from the type locality and horizon.

Type locality and horizon. Lower Eocene (Ypresian) London Clay of the Isle of Sheppey (Kent, England) (see Steurbaut and King, 2017; and references therein).

Main synonymies. Platemys bowerbankii Owen, 1842; Emys laevis Bell in Owen and Bell, 1849; Emys delabechii Bell in Owen and Bell, 1849; Emys conybearii Owen, 1858; Podocnemis bowerbankii (Owen, 1842) in Cope (1870); Podocnemis laevis (Bell in Owen and Bell, 1849) in Cope (1870); Palemys laevis (Bell in Owen and Bell, 1849) in Gray (1870); Palaeaspis conybearii (Owen, 1858) in Gray (1870); Palaeochelys bowerbankii (Owen, 1842) in Gray (1870); Peltocephalus laevis (Bell in Owen and Bell, 1849) in Rütimeyer (1873); Podocnemis bowerbanki (Owen, 1842) in Lydekker and Boulenger (1887); Podocnemis delabechi (Bell in Owen and Bell, 1849) in Lydekker and Boulenger (1887); Dacochelys delabechei (Bell in Owen and Bell, 1849) in Lydekker (1889a); Palaeaspis bowerbanki (Owen, 1842) in Williams (1954); Palaeaspis bowerbanki (Owen, 1842)
(Podocnemis bowerbanki (Owen, 1842)) in Rayner et al. (2009).

Emended diagnosis. Member of Bothremydini characterized by the following combination of characters: relatively large shell, exceeding $45 \mathrm{~cm}$; elongated and elliptical carapace, its length being almost 1.4 times that of its width; slightly wider than long nuchal plate; seven neurals, the first five being notably longer than wide, especially the first, which is more than twice as long as wide; antero-lateral margins of the first vertebral scute reaching the second pair of peripherals; first vertebral as wide as the second; first to third vertebrals wider than long; overlap of the first pair of marginals on more than half of the nuchal anterolateral margins; outer surface of the carapace and plastral plates lacking a well-developed ornamental pattern; long plastral bridge, longer than the plastral lobes; broad plastral lobes (the anterior being more than twice as wide as it is long), with sub-straight lateral margins; trapezoidal anterior lobe; short and wide anal notch; posterior end of the entoplastron anterior to the plastral bridge level; longer than wide mesoplastra; medial contact of the humeral scutes; overlap of the anterior region of the pectorals on the epiplastra; long overlap of the pectorals on the entoplastron; pectorals not reaching the anterior margins of the mesoplastra.

\section{DISCUSSION}

\section{Attribution of the Pleurodiran Turtles from the lower Eocene London Clay to a Single Species}

The detailed study of all the pleurodiran shells from the lower Eocene London Clay of the Isle of Sheppey (England) analyzed here, including the previously published specimens and other unpublished individuals (Figure 1), support their attribution to a single taxon. Adult specimens (e.g., Figure 1.1-6), but also juveniles (e.g., Figure 1.21-33), are identified. These juveniles show a lower degree of ossification between the plates, with disarticulations between some of the neurals, costals and peripherals, as well as between the peripherals and the plastral plates. As generally occurs during the ontogenetic development of extinct and extant taxa, the vertebral scutes of the juveniles are generally wider than those of the adults (pers. observ.). In addition, the presence of discontinuous, sinuous and anastomosed furrows is also generally better developed in the juveniles (Figure 1.27) than in the adults (Figure 1.7-8). The characters preserved in both juveniles and adults, recognized as being part of the exclusive diagnosis of this species, are com- 

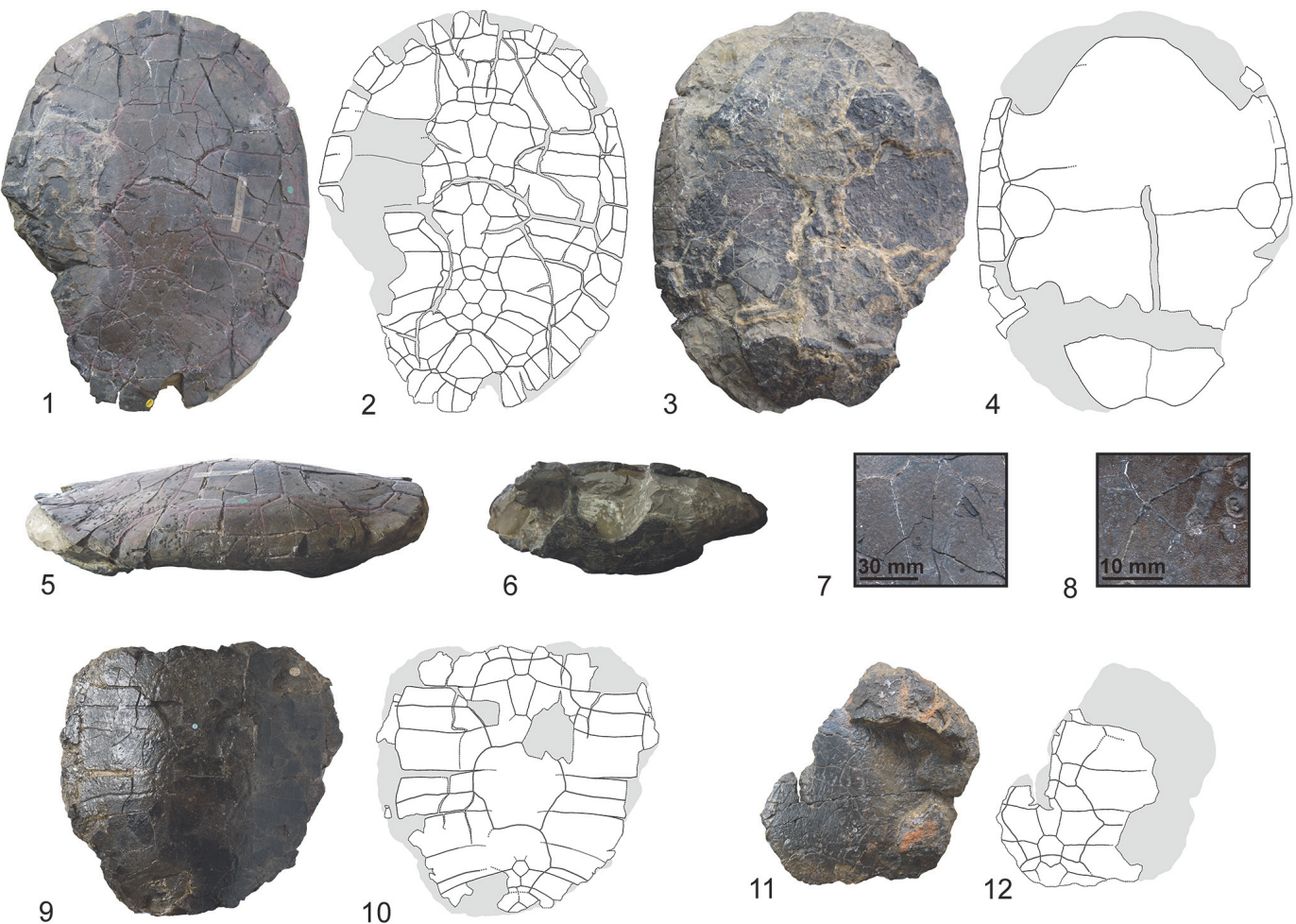

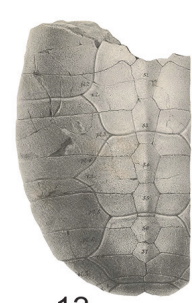

13

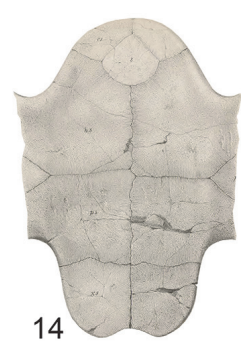

15
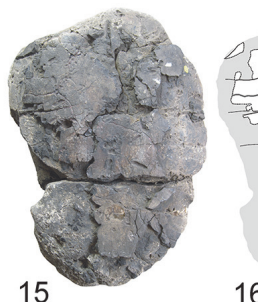

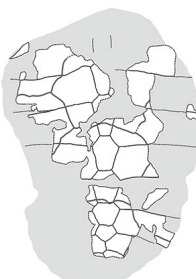

16

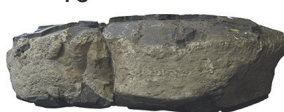

19

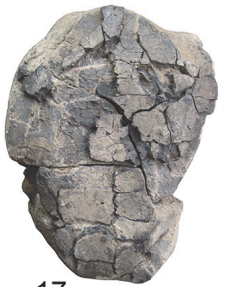

17

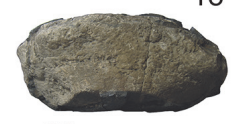

20
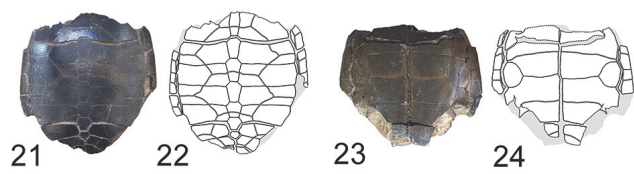

24
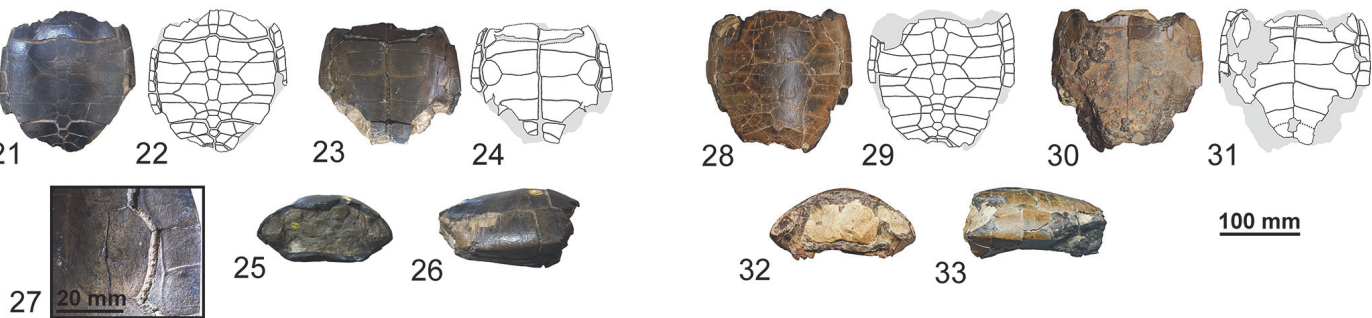

26

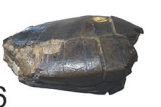

FIGURE 1. All currently known specimens of the coastal bothremydid turtle Palemys bowerbankii, from the lower Eocene London Clay of the la Isle of Sheppey (Kent, England). 1-8, NHMUK 39449, neotype of Palemys bowerbankii and holotype of 'Emys conybearii', in dorsal (1-2), ventral (3-4), right lateral (5) and posterior (6) views. 7-8, details of the outer surface, near the second (7) and the fifth neurals (8). 9-10, dorsal view of the holotype of 'Emys delabechii', GSM 6634. 11-12, dorsal view of the previously unpublished specimen NHMUK 39451. 13-14, drawings corresponding to the currently lost holotype of 'Platemys bowerbankii', in dorsal (13) and ventral (14) views. Taken from the plate XXIII of Owen and Bell, 1849. 15-20, the previously unpublished specimen NHMUK 39452, in dorsal (15-16) ventral (17-18), right lateral (19), and anterior (20) views. 21-26, holotype of 'Emys laevis', NHMUK 37209, in dorsal (21-22), ventral (23-24), anterior (25), and right lateral (26) views. 27, details of the outer surface, near the left mesoplastron. 28-33, shell without collection number, previously published by Clouter et al. (2000, page 73) and by Rayner et al. (2009, pag. 167), in dorsal (28-29) ventral (30-31), anterior (32), and left lateral (33) views. The scale for 1-26 and 2833 is the same. 

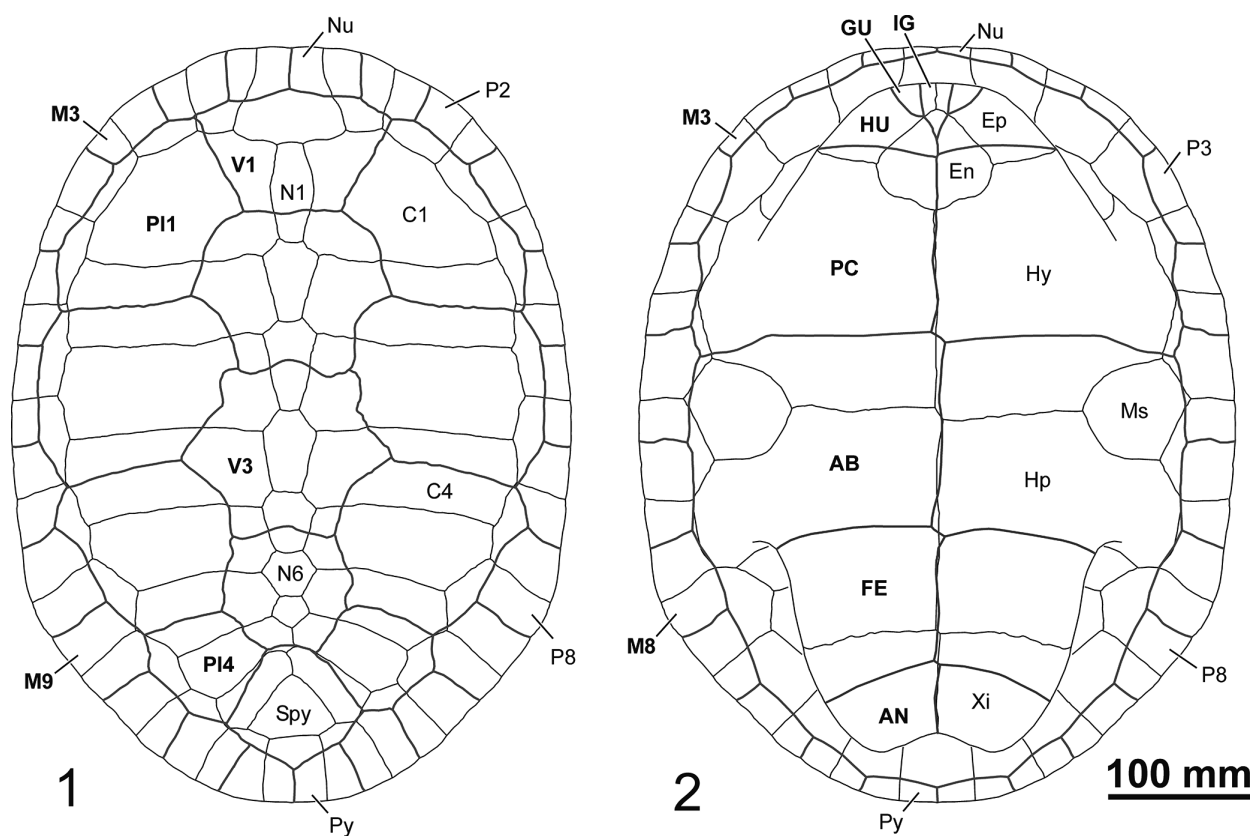

FIGURE 2. Reconstruction of the complete dorsal (1) and ventral (2) shell of an adult specimen of Palemys bowerbankii, from the lower Eocene London Clay of the Isle of Sheppey (Kent, England). Abbreviations for the plates: C, costal; En, entoplastron; Ep, epiplastron; Hp, hypoplastron; Hy, hyoplastron; N, neural; Nu, nuchal; Ms, mesoplastron; $\mathrm{P}$, peripheral; Py, pygal; Spy, suprapygal; $\mathrm{Xi}$, xiphiplastron. Abbreviations for the scutes (in bold and capital letters): $A B$, abdominal; $A N$, anal; FE, femoral; GU, gular; HU, humeral; IG, intergular; M, marginal; PC, pectoral; PL, pleural; $\mathrm{V}$, vertebral.

patible with its attribution to a single taxon. Thus, all of the specimens show the presence of seven neurals, the first five being noticeably longer than wide, especially the first one, which is more than twice as long as wide; the first to third vertebral scutes are wider than long; and the mesoplastra are longer than wide.

The presence of a supernumerary vertebral scute in the specimen NHMUK 39449 (Figure 1.12 ), located between the first and second vertebrals, is here considered as an anomaly. In addition to the variability in the width/length ratio of the vertebral scutes exhibited by the adult individuals (being especially wide in the lost holotype of 'Platemys bowerbankii' based on the plate XXIII of Owen and Bell, 1849; Figure 1.13-14), variability in the morphology and disposition of these scutes is identified. Thus, the contact between the third and fourth vertebrals is located on the posterior area of the fifth neural in the specimen NHMUK 39452 (Figure 1.15-16), but in a more anterior position in other specimens (e.g., Figure 1.1-2, 11-12, 21-22, 2829).

One of the specimens analyzed for the first time in this manuscript is NHMUK 39452 (Figure 1.15-20), which documents the subrhombic morphology of the entoplastron of this taxon, being wider than long. In addition, the arrangement of the humeral-pectoral sulcus on this plate can be recognized, the most probable locations of the intergular and gular scutes being interpreted (Figure 1.1718).

\section{Generic and Specific Attribution of the Pleurodiran Turtle from the lower Eocene London Clay}

In 1842, Owen defined 'Platemys bowerbankii' Owen (1842) by a single shell from the lower Eocene London Clay of the Isle of Sheppey, currently lost. A drawing of the specimen that had been attributed to 'Platemys bowerbankii' was subsequently published by Owen and Bell (1849, plate XXIII). The species 'Emys laevis' Bell in Owen and Bell (1849) and 'Emys delabechii' Bell in Owen and Bell (1849) were defined in 1849 , by two shells from the same fossiliferous area. A drawing of the only specimen attributed to 'Emys laevis' (now NHMUK 37209) was presented in the plate XXII of Owen and Bell (1849). The plate XXVIII of Owen and Bell (1849) is the drawing of 'Emys delabechii' (now specimen GSM 6634). The paper of Owen and Bell (1849) was published in July 1849. Another work of Owen was also published that month (i.e., Owen, 1849), in which the same draw- 
ings of the specimens of 'Emys laevis' (plate 3), 'Emys delabechii' (plate 37) and 'Platemys bowerbankii' (plate 39) were included. In addition, Owen (1849) recognized a partial skull as possibly attributable to 'Platemys bowerbankii' (plate 40, 1-2 in Owen, 1849; subsequently reproduced as figures 1 and 2 of the plate XXIX of Owen, 1850). This skull is currently recognized not as attributable to Pleurodira, but to Cryptodira (Gaffney et al., 2006). A new taxon from the lower Eocene London Clay, 'Emys conybearii' Owen, 1858, also from the Isle of Sheppey, was defined in 1858. Drawings of this shell, currently identified as NHMUK 39449, were represented on the plate XXVIII A-B of Owen (1858).

Cope (1870) proposed the new combinations 'Podocnemis bowerbankii' and 'Podocnemis laevis' for 'Platemys bowerbankii' and 'Emys laevis', respectively. Gray (1870) defined two new genera, Palemys and 'Palaeaspis', proposing the new combinations 'Palemys laevis' (represented by the holotype of 'Emys laevis', NHMUK 37209) and 'Palaeaspis conybearii' to which he attributed the holotype of 'Emys conybearii', NHMUK 39449. In addition, he correctly indicated that the genus Platemys Wagler, 1830, should not be employed for the species 'Platemys bowerbankii' (Platemys is currently recognized as a monospecific genus, represented by the extant chelid Platemys platycephala (Schneider, 1792)]. Therefore, he proposed a putative new genus for this species, Palaeochelys, generating the new combination 'Palaeochelys bowerbankii'. However, this generic name was previously employed by von Meyer (1847) for a wellrepresented member of Geoemydidae in the European Miocene record (Hervet, 2004). Rütimeyer (1873) recognized 'Emys laevis' as belonging to the extant South American genus Peltocephalus Duméril and Bibron (1835) proposing the new combination 'Peltocephalus laevis'. He considered that it probably corresponded to the same form as 'Platemys bowerbankii'. This synonymy was supported by Lydekker and Boulenger (1887). However, these authors reassigned this taxon to the genus Podocnemis Wagler (1830) as was previously proposed by Cope (1870). So, they supported the combination 'Podocnemis bowerbanki'. In addition, they indicated that 'Emys conybearii' appears specifically identical to 'Emys delabechii', proposing the new combination 'Podocnemis delabechi'. In 1889, Lydekker attributed a partial and isolated lower jaw to the new genus Dacochelys, indicating that it could correspond to the same taxon as 'Emys delabechii'.
Thus, he indicated that, if this could be confirmed, the combination 'Dacochelys delabechei' would be established (Lydekker, 1889b). In the Catalogue of the Fossil Reptilia and Amphibia in the British Museum, Lydekker (1889a) supported his previous identification of two possible forms, Podocnemis bowerbanki and 'Dacochelys delabechei'. Although the lower jaw of Dacochelys is lost, the information provided by Lydekker $(1889 a$, b) refutes its attribution to Pleurodira (de Broin, 1977).

Williams (1954) reproduced the previously published drawings of 'Emys conybearii' (figure 1), 'Emys laevis' (figure 2), 'Emys delabechii' (figure 3) and 'Platemys bowerbankii' (figure 4). The comparison between all previously published specimens led him to the belief that all the pleurodires of the London Clay were synonymous. Taking into account the absence of a detailed study of these forms, and the lack of new specimens, subsequent authors indicated that more than one species could be represented (de Broin, 1977; Gaffney et al., 2006). The attribution of all these specimens to a single species is supported here (see above). Assuming this, and considering the proposal of the two new generic names Palemys and 'Palaeaspis' in a single publication (see Gray, 1870), Williams (1954) chose 'Palaeaspis' as the valid generic name, because it included the most complete specimen. Therefore, he proposed the new combination 'Palaeaspis bowerbanki'. The name Palemys was proposed by Gray (1870) in pages 49-51, but Palaeaspis was proposed in pages 71 and 73 . Therefore, the priority should be that of Palemys, the identification of one specimen as more complete than the other not being relevant. Considering Article 23.9.1.2. of the International Code of Zoological Nomenclature, the proposal of Williams (1954) could only be correct if the putative junior synonym (i.e., 'Palaeaspis') was used for the taxon, as the presumed valid name, in at least 25 works, published by at least 10 authors in the immediately preceding 50 years of that publication, and encompassing a span of not less than 10 years. Because this condition was not met, the first proposed generic name, Palemys, is considered here as the valid. Thus, the new combination Palemys bowerbankii is proposed.

\section{Phylogenetic Position of Palemys bowerbankii and Comparison with Other European Paleogene Forms}

Owen (1842) indicated that 'Platemys bowerbankii' probably belonged to the 'Platemydian' division of the family 'Chelonia'. A few years later, 
Owen (1849) included this species, and the others here recognized as synonymous, as belonging to the order 'Chelonia' and the family 'Paludinosa'. Gray (1870) attributed 'Palemys laevis' to the family 'Dermatemydae', 'Palaeochelys bowerbankii' to 'Chelydrade' and 'Palaeaspis conybearii' to 'Hydraspididae'. The same year, Cope (1870) recognized 'Podocnemis bowerbankii' and 'Podocnemis laevis' as members of Pleurodira, including them in the Podocnemididae. Rütimeyer (1873) supported the attribution of both species to Podocnemididae. However, he indicated that it was difficult to say whether 'Emys conybeari' and 'Emys delabechi' belonged to the Emydidae or the 'Chelydidae'. Lydekker and Boulenger (1887), which recognized the presence of two species ('Podocnemis bowerbanki' and 'Podocnemis delabechi'), supported the interpretation that they were members of Podocnemididae. Williams (1954) considered the only form recognized by him, 'Palaeaspis bowerbanki', as a member of Pelomedusidae, an attribution supported by de Broin (1977). However, de Broin (1988) indicated its possible attribution to Podocnemididae, subsequently reattributing it to Bothremydidae (Lapparent de Broin and Werner 1998; Lapparent de Broin, 2001). Gaffney et al. (2006) recognized these shells as belonging to Pelomedusoides incertae sedis because these attributions were not justified, due to the lack of information about the pleurodires from the lower Eocene London Clay, and taking into account the doubt whether they could correspond to single or more than one forms. Several characters recognized by Lapparent de Broin et al. (under preparation), including those relative to the morphology of both the carapace and the plastron, and the length of the plates of the anterior region of the carapace, confirms the attribution of this taxon to Bothremydidae. However, it was never included in a cladistic analysis, so its phylogenetic position within this clade is not known.

The phylogenetic analysis performed as part of this study resulted in 16 most parsimonious trees, with a length of 306 steps $(\mathrm{Cl}=0.696$; $\mathrm{RI}=0.771$; $\mathrm{RC}=0.537$ ) (Figure 3). Palemys bowerbankii is obtained as a member of Bothremydini Foxemydina, a clade composed of several Santonian to lower Eocene European forms. The Colombian Paleocene Puentemys mushaisaensis Cadena et al., 2012 is also obtained as a member of this clade (as in some previous phylogenetic hypotheses, such as those of Cadena et al., 2012, and Pérez-García, 2016a; but not in Pérez-García, $2016 b)$. In addition to several cranial characters,
Foxemydina is defined here by the overlap of the anterior region of the pectoral scutes on the epiplastra (character 166, state 1; not shared with some specimens of Puentemys mushaisaensis), and by the presence of the first vertebral scute wider than the second (character 178, state 2; not shared with some specimens of Foxemys mechinorum Tong et al., 1998 and with Palemys bowerbankii). Palemys bowerbankii is obtained as part of a polytomy, composed of three branches: this species, the node composed by the French Campanian Polysternon provinciale (Matheron, 1869) and the French Ypresian Tartaruscola teodorii, and that composed by the Hungarian Santonian Foxemys trabanti Rabi et al., 2012, the French CampanoMaastrichtian Foxemys mechinorum, and Puentemys mushaisaensis. Both nodes are defined, in this analysis, by cranial characters. Palemys bowerbankii is characterized by the presence of the first vertebral scute as wide as the second (character 178 , state 1). This state of character is also shared with some specimens of Foxemys mechinorum.

A second bothremydid had been described in the European lower Eocene record: the French Ypresian Tartaruscola teodorii. Although the type material corresponded to two skulls, several nuchal plates from the type locality, belonging to both juvenile and adult individuals, had been referred to this taxon (Pérez-García, 2016b). These nuchals are noticeably longer than wide, the length being about $20 \%$ higher than the maximum width. The lateroanterior margin of each nuchal is more than twice as long as the lateroposterior. The length of the anterior nuchal margin is similar to half of the maximum width of these plates. The outer surface of the plates belonging to adult individuals is markedly rough. Therefore, remarkable differences are recognized between Palemys bowerbankii and this synchronous taxon.

Another member of Bothremydidae has been recognized in the European Paleogene record: the French Oligocene 'Chrysemys' montolivensis Roman (1897). This form is represented by a partial carapace, which lacks both the nuchal plate and a large part of the anterior plastral lobe. Its first neural is interpreted as noticeably shorter than that of Palemys bowerbankii, and the vertebral scutes are narrower, the second to fourth being as long as wide. In addition, their pectoral scutes overlap the anterior area of the mesoplastra. Therefore, Palemys bowerbankii differs from the other members of Bothremydidae so far defined in the European Paleogene record. 


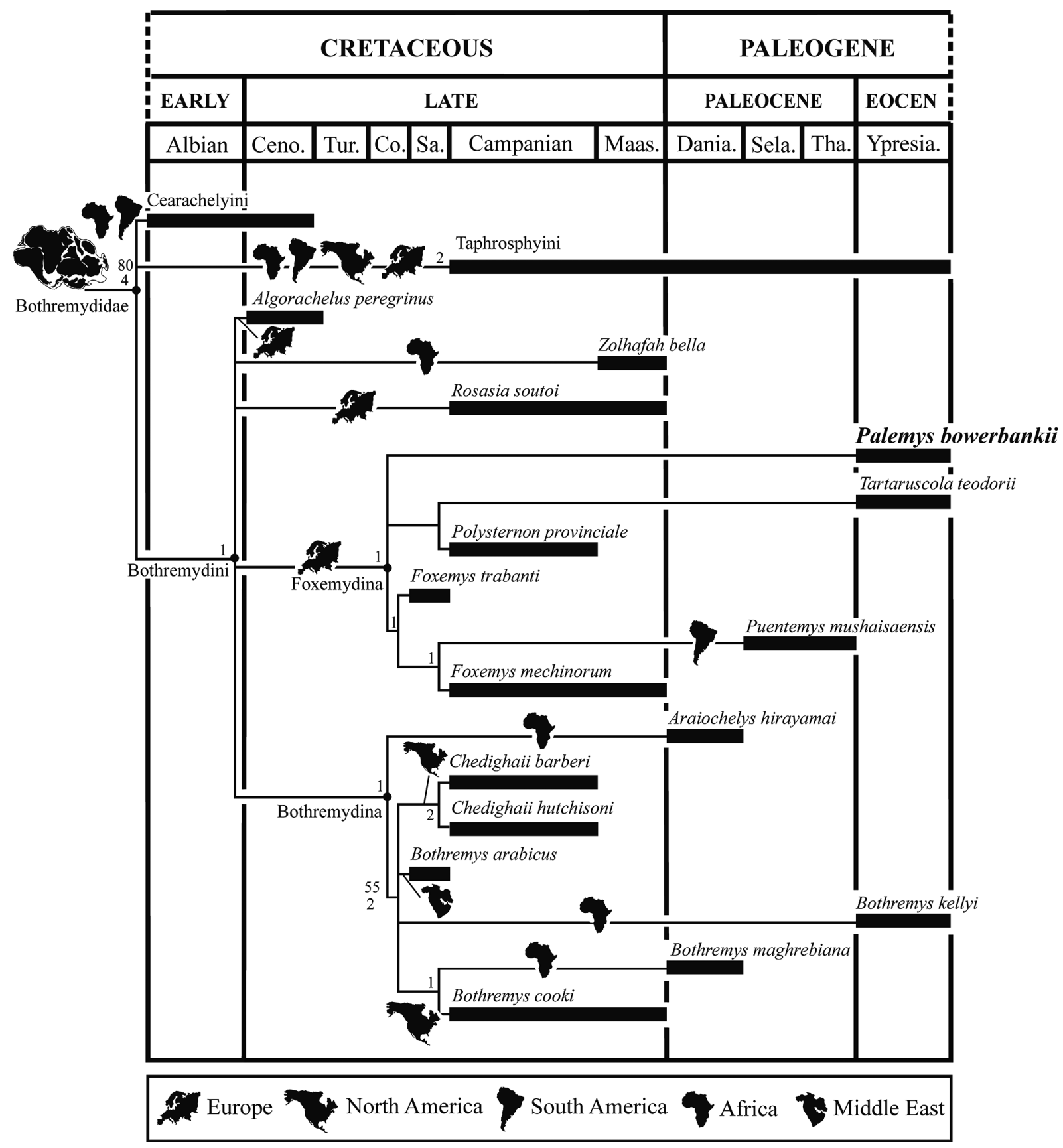

FIGURE 3. Phylogenetic position of Palemys bowerbankii (Pleurodira, Bothremydidae), from the lower Eocene London Clay of the Isle of Sheppey (Kent, England), in the strict consensus tree obtained by the cladistic analysis performed here. Bootstrap frequencies (top; only values equal to or greater than $50 \%$ shown) and Bremer support values (bottom) are indicated. The continents where each of these taxa were found are indicated.

Several dispersal events of Pelomedusoides from Africa to Europe are recognized in the Cenozoic record (see Pérez-García, 2017, and references therein). The identification of Palemys bowerbankii as a member of Foxemydina (i.e., a well-represented lineage in the European upper- most Cretaceous record), suggests that this British coastal bothremydid probably does not represent the result of a Cenozoic dispersal event from Africa but that it could be the descendant of European Cretaceous forms. 


\section{CONCLUSIONS}

Pleurodiran turtles are relatively abundant in both the Upper Cretaceous and the Paleogene records of Continental Europe, being represented by continental and coastal members of two lineages of Pelomedusoides: Podocnemididae and Bothremydidae. However, the British record of Pleurodira is much more limited, being restricted to two lower Eocene coastal forms. One of them is an indeterminate species of the podocnemidid Eocenochelus, represented by a recently described single specimen from the Ypresian (early Eocene) of Bracklesham Bay (Sussex, England). Eocenochelus is a member of a lineage of African origin, which reached Europe during the Paleogene, and is present in several European countries: Great Britain, Belgium, France, Spain and Italy.

A second member of Pelomedusoides is recognized in the British Ypresian record. It is represented by several specimens from the London Clay of the Isle of Sheppey (Kent, England). Several shells were identified there, since the 19th century. Some of these classic specimens were the basis for the description of four putative new species. The detailed study of the classic specimens, as well as that of others found subsequently (including several unpublished ones), confirms that they can be attributed to a single species, for which the new combination Palemys bowerbankii (Owen, 1842) is proposed. Therefore, Palemys bowerbankii, is the only pleurodiran turtle currently recognized in the British record at specific level. A neotype is designated here, and a new diagnosis is provided. Photographs of most of the classic specimens of Palemys bowerbankii are included here for the first time. In this way, knowledge about this form is improved and a reconstruction of its complete shell is performed. Characters and elements hitherto unknown for this species are described, and intraspecific variability, affecting several characters, is recognized. The comparison of this British form with the other Paleogene European bothremydids allows Palemys to be recognized as an exclusive form of the British record. Its inclusion in a cladistic analysis shows its belongs to a lineage well-represented in the European Upper Cretaceous record, Foxemydina, in contrast to the other member of Pelomedusoides present in the British record, Eocenochelus, which represented the result of a Cenozoic dispersal event from Africa to Europe.

\section{ACKNOWLEDGEMENTS}

This research has been funded by the Ministerio de Economía, Industria y Competitividad (FPDI-2013-18986, IJCl-2016-30427 and CGL2015-68363-P). The author thanks S.J. Harris and P.S. Shepherd (BGS, UK), N.D.L. Clark (The Hunterian, University of Glasgow, UK), D. Rayner and T. Mitchell (UK), S.D. Chapman (NHMUK, UK) and $F$. de Lapparent de Broin (Muséum national d'Histoire naturelle, Paris) for the information provided and the access to the specimens studied here; and the editors and the reviewers (E. Cadena and D. Brinkman) for their comments and suggestions. The Willi Hennig Society sponsors the TNT cladistics software.

\section{REFERENCES}

Bardet, N., Falconnet, J., Fischer, V., Houssaye, A., Jouve, S., Pereda Suberbiola, X., PérezGarcía, A., Rage, J.-C., and Vincent, P. 2014. Mesozoic marine reptile palaeobiogeography in response to drifting plates. Gondwana Research, 26:869-887. https://doi.org/10.1016/ j.gr.2014.05.005

Batsch, G.C. 1788. Versuch einer Anleitung, zur Kenntniss und Geschichte der Thiere und Mineralien. Akademische Buchhandlung Jena, 1:1-528.

Baur G. 1887. Ueber den ursprung der extremitäten der ichthyopterygia. Berichte Über de Versammlungen des Oberrheinischen Vereines, 20:17-20.

Baur, G. 1891. Notes on some little known American fossil tortoises. Proceedings of the Academy of Natural Sciences of Philadelphia, 43:411-430.

Bergounioux, F.-M. 1954. Les Chéloniens fóssiles des terrains tertiaires del Vénétie. Memoire degli istituti di Geologica e Mineralogia dell'Università di Padova, 18:1-115.

Cadena, E.A., Bloch, J.I., and Jaramillo, C.A. 2012. New bothremydid turtle (Testudines, Pleurodira) from the Paleocene of northeastern Colombia. Journal of Paleontology, 86:688698. https://doi.org/10.1666/11-128R1.1

Clouter, F., Mitchell, T., Rayner, D., and M. Rayner. 2000. London Clay Fossils of the Isle of Sheppey. Medway Lapidary and Mineral Society, Gillingham, England. 
Cope, E.D. 1864. On the limits and relations of the Raniformes. Proceedings of the Academy of Natural Sciences of Philadelphia, 16:181-183.

Cope, E.D. 1868. On the origin of genera. Proceedings of the Academy of Natural Sciences of Philadelphia, 20:242-300.

Cope, E.D. 1870. Synopsis of the extinct Batrachia, Reptilia and Aves of North America. Transactions of the American Philosophical Society, 14:1-252.

de Broin, F. 1977. Contribution à l'étude des Chéloniens. Chéloniens continentaux du Crétacé et du Tertiaire de France. Mémoires du Muséum national d'Histoire naturelle, 38:1-366.

de Broin, F. 1988. Les tortues et le Gondwana. Examen des rapports entre le fractionnement du Gondawana et la dispersion géographique des tortues pleurodires à partir du Crétacé. Studia Geologica Salmanticensia, Studia Palaeocheloniologica, 2:103-142.

Duméril, A.M.C. and Bibron, G. 1835. Erpétologie Générale ou Histoire Naturelle Complète des Reptiles. Vol. 2. Librairie Encyclopédique de Roret, Paris.

Gaffney, E.S., Tong, H., and Meylan, P.A. 2006. Evolution of the side-necked turtles: the families Bothremydidae, Euraxemydidae, and Araripemydidae. Bulletin of the American Museum of Natural History, 300:1-700.

Goloboff, P.A., Farris, J.S., and Nixon, K.C. 2008. TNT, a free program for phylogenetic analysis. Cladistics, 24:774-786. https://doi.org/10.1111/j.1096-0031.2008.00217.x

Gray, J.E. 1870. Supplement to the Catalogue of the Shield Reptiles in the Collection of the British Museum. Part I. Testudinata (tortoises). British Museum, London.

Hervet, S. 2004. Systématique du groupe 'Palaeochelys sensu lato - Mauremys' (Chelonii, Testudinoidea) du Tertiaire d'Europe Occidentale: principaux résultats. Annales de Paléontologie, 90:13-78. https://doi.org/10.1016/j.annpal.2003.12.002

Joyce, W.G., Chapman, S.D., Moody, R.T.J., and Walker, C.A. 2011. The skull of the solemydid turtle Helochelydra nopcsai from the Early Cretaceous of the Isle of Wight (UK) and a review of Solemydidae. Special Papers in Palaeontology, 86:75-97.

Lapparent de Broin, F. de and Werner, C. 1998. New late Cretaceous Turtles from the western Desert, Egypt. Annales de Paléontologie, 84:13I-214. https://doi.org/10.1016/S07533969(98)80005-0

Lapparent de Broin, F. de. 2001. The European turtle fauna from the Triassic to the Present. Dumerilia, 4:155-216.

Lydekker, R. 1889a. Catalogue of the fossil Reptilia and Amphibia in the British Museum (Natural History). Part III. The Order Chelonia. British Museum (Natural History) by order of the Trustees, London.

Lydekker., R. 1889b. On remains of Eocene and Mesozoic Chelonia and a tooth of (?) Ornithopsis. Quarterly Journal of the Geological Society of London, 45:227-246.

Lydekker, R. and Boulenger, G.A. 1887. Notes on Chelonia from the Purbeck, Wealden and London Clay. Geological Magazine, 4:270-275.

Matheron, P. 1869. Notice sur les reptiles fossils des dépots fluviolacustres crétacés du bassin à lignite de Fuveau. Mémoires de l'Académie Impériale des Sciences, Belle-Lettres et Arts de Marseille, 1:1-39.

Owen, R. 1842. Report on British fossil reptiles. Part II. Report of the British Association for the Advancement of Science, 1842:60-204

Owen, R. 1849. A History of British Fossil Reptiles. Vol. II. Museum of Comparative Zoology, Harvard.

Owen, R. 1850. Monograph on the fossil reptilia of the London Clay, and on the Bracklesham and other Tertiary beds. Paleontological Society of London, Monograph 2, Part 2, Supplement 1:1-4.

Owen, R. 1858. Monograph on the fossil reptilia of the London Clay, and on the Bracklesham and other Tertiary beds. Paleontological Society of London, Monograph 2, Part 1, Supplement 1:77-79.

Owen, R. and Bell, T. 1849. Monograph on the fossil reptilia of the London Clay, and on the Bracklesham and other Tertiary beds. Paleontological Society of London, Monograph 2, Part 1:1-76.

Pérez-García, A. 2012. High diversity of pancryptodiran turtles in the Lower Cretaceous of Europe. Cretaceous Research, 36:67-82. https://doi.org/10.1016/j.cretres.2012.02.004

Pérez-García, A. 2016a. A new turtle taxon (Podocnemidoidea, Bothremydidae) reveals the oldest known dispersal event of the crown Pleurodira from Gondwana to Laurasia. Journal of Systematic Palaeontology, 2016:1-23. https://doi.org/10.1080/14772019.2016.1228549 
Pérez-García, A. 2016b. A new turtle confirms the presence of Bothremydidae (Pleurodira) in the Cenozoic of Europe and expands the biostratigraphic range of Foxemydina. The Science of Nature, 103:50. https://doi.org/10.1007/s00114-016-1375-y

Pérez-García, A. 2017. The Iberian fossil record of turtles: an update. Journal of Iberian Geology, 43:155-191. https://doi.org/10.1007/s41513-017-0016-4

Pérez-García, A. and Chapman, S.D. 2017. Identification of Podocnemididae (Pleurodira) in the British record by the first specimen of the coastal Eocenochelus recognized outside Continental Europe. Proceedings of the Geologists' Association, 128:757-763. https:// doi.org/10.1016/j.pgeola.2017.06.001

Pérez-García, A. and Smith, T. 2017. Identification of the African-European Erymnochelys group (Pleurodira, Podocnemididae) in the Belgian fossil record: first finding of Eocenochelus eremberti outside its type locality. Fossil Record, 20:245-251. https://doi.org/10.5194/fr-20245-2017

Pérez-García, A., Lapparent de Broin, F. de, and Murelaga, X. 2017. The Erymnochelys group of turtles (Pleurodira, Podocnemididae) in the Eocene of Europe: new taxa and paleobiogeographical implications. Palaeontologia Electronica, 20.1.14A:1-28. https:// doi.org/10.26879/687

Rabi, M., Tong, H., and Botfalvai, G. 2012. A new species of the side-necked turtle Foxemys (Pelomedusoides: Bothremydidae) from the Late Cretaceous of Hungary and the historical biogeography of the Bothremydini. Geological Magazine, 149:662-674. https://doi.org/ 10.1017/S0016756811000756

Rayner, D., Mitchell, T. Rayner, M., and Clouter, F. 2009. London Clay Fossils of Kent and Essex. Medway Fossil and Mineral Society, Rochester, England.

Roman, F. 1897. Recherches stratigraphiques et paleontologiques dans le Bas-Languedoc. Annales de l'Université de Lyon, 1897:1-366.

Rütimeyer, L. 1873. Die fossilen Schildkröten von Solothurn und der übrigen Juraformation. Neue Denkschriften der Allgemeinen Schweizerischen Gesellschaft für die Gesammten Naturwissenschaften, 25:1-185.

Schneider, J.G. 1792. Beschreibung und Abbildung einer neuen Art von Wasserschildkröte nebst Bestimmungen einiger bisher wenig bekannten fremden Arten. Schriften der Gesellschaft Naturforschender Freunde zu Berlin, 10:259-283.

Steurbaut, E. and King, C. 2017. The composite Kortrijk section (W Belgium): a key reference for mid-Ypresian (Early Eocene) stratigraphy in the southern North Sea Basin. Geologica Belgica, 20:125-159. https://doi.org/10.20341/gb.2017.008

Tong, H., Gaffney, E.S., and Buffetaut, E. 1998. Foxemys, a new side-necked turtle (Bothremydidae: Pelomedusoides) from the Late Cretaceous of France. American Museum Novitates, 3251:1-19.

von Meyer, H. 1847. Palaeochelys bussenensis im älteren Süsswasserkalk. Jahreshefte des Vereins für Vaterländische Naturkunde in Württemberg, 3:167-168.

Wagler, J. 1830. Natürliches System der Amphibien, mit Vorangehender Classification der Säugethiere und Vögel. Cotta, Munich.

Williams, E.E. 1954. Fossils and the distribution of chelyid turtles on northern continents. 2. Additional reputed chelyid turtles on northern continents: Palaeaspis conybearii (Owen)-a Pelomedusid. Breviora, 32:1-6. 


\section{APPENDIX 1.}

Coding of Palemys bowerbanki in the data matrix proposed by Pérez-García (2016a).

????????? ?????????? ????????? ?????????? ?????????? ?????????? ??????????

?????????? ?????????? ?????????? ?????????? ?????????? ?????????? ???????11?

2?1022?121 210????211 ?111111?10 10111?[01]10?

\section{APPENDIX 2.}

Nexus file corresponding to the data matrix used in this paper available in a zipped file at https:// palaeo-electronica.org/content/2018/2268-british-bothremydid-turtle. 